\title{
The Great Romance: a science fiction/utopian novelette
}

\author{
Dominic Alessio
}

The Great Romance, a science-fiction/utopian novelette, was published in two separate volumes in New Zealand in 1881 . The first volume comprises 55 pages and, until recently, was apparently listed in only one published bibliography, Bagnall's New Zealand National Bibliography to the Year 1960. The sole known original copy of volume 1 exists in the Alexander Turnbull Library (ATL), Wellington. Unlike the first volume, however, the second was presumed lost until the rediscovery of a single copy (of 39 pages) in the Hocken Library, Dunedin (ref: PA 176/5). Apparently it had once formed part of Dr. Hocken's original collection. Both volumes are now included in Lyman Tower Sargent's bibliography of New Zealand utopian literature. The novel, however, remains virtually unknown and has received attention only in specialist SF publications (Alessio 1993, 1995).

The ATL copy of volume 1 has two title pages, one making Dunedin the place of publication, the other, Ashburton. The Dunedin title page was printed at the 'Daily Times' office, the Ashburton one at 'The Guardian' office. Bagnall, whose bibliographic entry is presumably based on the ATL copy, gives the place of publication as Ashburton, without offering any explanation for the discrepancy in the title pages. Since the Dunedin title is printed on yellow paper, whereas the paper of the Ashburton title and the rest of the novelette is white, and since nearly all the advertising is for Ashburton business firms, it seems likely that the Turnbull copy was printed entirely at Ashburton and that there was a special issue for Dunedin with different advertising. ${ }^{1}$

The author's name is given as 'The Inhabitant', a pseudonym common at the time for guidebooks in the United Kingdom and the United States. The choice of nomenclature appears appropriate for the work since both volumes purport to be, in part, a kind of guidebook from the point of view of a twentieth century traveller (John Brenton Hope) and his future-earth companions: volume 1 to a 22nd century Earth and an interstellar voyage of exploration, and volume 2 to the planet Venus. The second volume ends 
abruptly with Hope's encounter with native 'Venuses' and his companions' dangerous return voyage to Earth. As to the true identity of 'The Inhabitant', however, apart from the fact that Bagnall identifies one Honnor of Ashburton, nothing further is known.

The Great Romance is important both in the history of SF and in the history of New Zealand literature. First, the work's frame story appears to be the inspiration for Edward Bellamy's Looking Backward 2000-1887 (1888), the most influential and widely read of all utopias. Secondly, it is another indicator of how widespread the writing and publishing of SF and utopian literature was in the 19th century. Thirdly, its rational 'science' element dealing with space travel in particular, makes it (along with Percy Greg's 1880 publication of Across the Zodiac), a pivotal departure in SF. And fourthly, the work fits into a tradition of utopian/SF literature with a New Zealand thrust or theme, including the writings of such well-known authors as Samuel Butler, Jules Verne and Anthony Trollope.

Volume 1 is now reprinted below, Volume 2 will be republished in Kotare in March 1999 and an extended introduction to both will follow in the September 1999 issue of the journal. It is hoped that the resuscitation of a 'lost' yet nevertheless important New Zealand publication might lead to further research on the work. Perhaps eventually such research can shed light on the identity of the author, whether or not a volume 3 exists, and the possible connection between New Zealand and Edward Bellamy.

In the reproduction which follows the sometimes idiosyncratic punctuation has been lightly edited and obvious errors of spelling have been corrected without notice.

\section{WORKS CITED}

Alessio, Dominic, ed. 'The Great Romance, by The Inhabitant.' Science-Fiction Studies 20 no.61 (November 1993): 305-340.

Alessio, Dominic. 'An Introduction to The Great Romance.' Phlogiston 44 (1995): 9-10.

Bagnall, A.G. New Zealand National Bibliography to the Year 196o. Wellington: A. R. Shearer, 1969.

Sargent, Lyman Tower. New Zealand Utopian Literature: An Annotated Bibliography Wellington: Stout Research Centre, 1996.

\section{ENDNOTE}

${ }^{1}$ I am grateful to R. D. Mullen for his valuable suggestions here. 


\title{
The Great Romance
}

\section{By The Inhabitant}

\author{
I \\ WILL \\ TELL YOU \\ A TALE WILDER \\ THAN POET EVER DREAMED! \\ YEA, STRANGER THAN \\ THE VISION OF \\ THE MADDEST \\ PROPHET! \\ TO JOHN KEATS, \\ TO WHOSE MEMORY \\ THE VOLUMES OF THE GREAT ROMANCE ARE \\ RESPECTFULLY DEDICATED \\ O, thou whose voice, as from the setting sun, \\ As from the land where old gods deathless lie, \\ Poured in my heart like an Archangel's trump, \\ Wakening a deathless memory, which to day, \\ The offspring of past blisses and deep joys \\ Unto the outer air doth feebly cry. \\ O, hush in billowy volumes, low and sweet \\ As love and birth, passion and strange pain mixed \\ The sound doth creep, yea folds me round \\ As I have felt, when past the light of day, \\ The darkness dumbly creep into my brain, \\ A prelude dim and strange as of eternal sleep.
}




\section{CHAPTER I.}

"What is it?" I said.

I awoke and tried to collect my thoughts. Before me stood a man; I don't like to confess it, but a glance told me a much better man than myself.

I was just awakened. Then gradually there stole into my mind the past facts.

"What year is it?" and the man lifted his eyes and looked straight into mine. Was he a mesmerist? Something from his look seemed to wander around my brain and try to find an entrance.

"Two thousand one hundred and forty-three," I said. A ridiculous guess, I thought at the same moment.

Again the man lifted his eyes, and before I could think again I said to myself, "You are right."

I was abashed, and turned my eyes to the ground. Then it all came back to me.

In the year one thousand nine hundred and fifty my dearest friend, John Malcolm Weir, the greatest chemist of his day, had given me the sleeping draught: it should tie up the senses-life itself-for an indefinite period; and when the appointed years were over life might again be awakened.

Yes, I recollect, I was depicted in Punch as the "Sleeping Beauty," just a week or two before I went off. Yes, and John Weir on the next page, drinking the elixir of life, while, with his finger on his nose, his thumb pointed me out in the corner. Yes, Punch started three large-sized engravings just before. I suppose wit was growing more plentiful. Moxton had the third-great chemist, too-great everything: the philosopher's stone-but that was not so good. Punch could only write "Coal" on one heap and "Gold" on another. I always advocated his going into colours; but-what? Did someone speak?-did someone say ...

"The one thing we have not yet found out?"

I looked at my companion. He had grand eyes, and now they were bent on me with a wonderful power and interest.

"Confound the man, does he think I am a woman?" My hand naturally sought my chin; the large growth of hair quite relieved me. I looked again. The man before me looked up. He had evidently been blushing. I looked hard. Good God! He had no hair on his face; he was very young. His eyes fell to the ground. His garments were the garments of a man; but-what-I must confess my thoughts did wander wild. Yet, as my eyes returned and 
once again met his-yes, his-I knew it instantly. If I had been sleeping a thousand years I should have known it. If I had been lying on a couch for ten thousand years I should have jumped up, as I did then, as he advanced towards me.

"Why will you make me speak? Why do you think so animal-like of woman? If you have no curb for your spirit, know that almost every one you meet can read your thoughts."

We are startled out of exclamation and fear when some sudden immense fact breaks like light on the mind. I looked hard at my companion as he stood before me. A wondrous, glorious feeling-awe, benevolence, love, enjoyment, seemed to come round about me, almost to enter into my life, as I met his steady gaze.

I was on the point of speaking; something-I cannot recollect what-was rising in my brain, when he again opened his lips.

"Why do you want to speak?"

I could only gaze in astonishment.

He continued, "I thought it must be so." Then, in a still sweeter tone, he said, "We do not often speak now," and, as his face grew troubled, "Your mind is more than irregular; try to cleanse and calm it while only I am here; it will hurt you else in after years to think that others saw it thus. Yes, I believe it would have been better to have made your sleep death, soon after your friend left this world; but the older men would not hear of it. You first started the mechanical world on this new track. You found out that power which so swiftly drives us through the air and over the earth; so, not to seem ungrateful even to a straying thought, we let you sleep on."

I have many times felt a thrill of pleasure when, in doubt or difficulty, a trusted friend has taken my hand, and I have been assured that through everything he would stand by me. But that was but a semblance-a faint sketch-of the thrill that went through me as my companion stretched out his hand to me, and a voice seemed to wind round me again, saying, "Think nothing you would be ashamed to put into words and acts; no, not even in a desert, for, though your friends may be now on the other side of the world, they may afterwards catch the imprint of your thoughts." But yet the man was only looking at me. It was confusing.

I said to him, "How old are you?"

He would not speak, but smiled.

I said to myself, "Twenty-one."

"Yes," he replied, "cannot you think with me?" 
But as I did not answer, he went on, "We need not to speak for utility, only when we wish for the melody of the voice; we can read so well each other's thoughts, conversing for hours, without a word."

"Oh!" said I, "that was one of the things Punch never thought of, and if he had I don't know how he would have managed it."

"Ah, Punch," said my companion. "An old, old paper; we keep it going yet, but we have regulated his features considerably."

I was still looking at the young man, but as he mentioned the features of Punch an idea of my own looks stole before me. I was conscious of ugliness-but I recollect I was not thought an ill-looking man; never saw my bad points before.

These thoughts, though they take time to read, took no appreciable time to think.

My companion instantly began, "I beg your pardon, sir-forgive my rudeness."

"What do you mean?" said I.

He answered, "I ought, perhaps, to warn you, as I think this may be a new trouble. Sir, this time which you have slept has helped on fast the work on which you must have noticed the beginning; re-cast the human face and figure improved it-beautified it." And again the man smiled, with an earnest, beautiful expression. I doubt not many pleasant thoughts were passing in his mind, but I could catch none of them. Then he went on.

"You will suffer most from women; when they see you, often, often, I fear, will their thoughts revert to your looks (this young man was just twenty-one). Their minds are less controllable than man's. If you read our best photographic histories you will learn that when men began to read each other's thoughts, all thoughts that were not good or inharmonious had to be banished, at first only with friends, then everywhere. The man that passed you in the street would turn round to look at you. Then it was too late, he knew your thoughts. And now no place is safe for any evil; as your thoughts grow strong-and all evil things do, ere they bloom to fruition-they get rampant, like a weed in a garden; then some other mind catches the vibration, and the world knows crime is almost impossible, for great deeds of wickedness would appear written on the brain in shining letters. Men have asked to be destroyed for very shame, men with great minds, too, yet so mixed with vile relics of the past that they were in a perpetual hell." 
I thought, half-bitterly, that I should like to go to them. I suppose the man read my thoughts, for he seemed to answer them.

“'Ah, yes', I said to my father, 'it were better.' As I looked on you I said, 'Ah, why should he ever wake?"'

A cold feeling ran over me as he said these words.

"But you would not kill a man for thinking evil?"

The start, the flush, the look of bewilderment did me good.

"Kill a man before he wished to die! Do I interpret your thoughts? Why should we not go back and eat the human flesh, and drink the blood? Oh, faugh. Do not think thus. Oh, banish that worst relic of the past, that disennobling fear, which has scarce so appeared in the human face this half century"-he checked himself a little-"at least not among the higher races."

"But," I said, "where are those men now? What did you do with them?"

"Some are yet struggling around this world, some will even drink of the aqua vitae. Like you, they fear to lose their being-it is for them, however, sad and hard-and they gradually lose respect, for the new generations are moulded to the present time: beautiful, strong-and I must use for you the old word-holy. He who outlives nature's limits, except under peculiar circumstances, is thought to be fearful-a weak man. Yet I tell you this, amongst the younger men and women, the old idea of perpetual life is reviving, and although we have never flown beyond this planet, only perfected your thought, we are dreaming now of other worlds-of Mars and Venus. Could we reach them and inhabit them life might again increase. I don't think we should feel degraded, at least for two or three hundred years."

Oh, what a wild hope sprang up in my heart as he spoke these words. And then he smiled as he continued:

"Some rash philosophers say that we are perfection, that it was the change from speech to thought that so swiftly altered the human type; the change from half evil to good, by that made necessary, which so improved the human features. But all these things we leave to time, or until another genius like you shall come."

"Sir," I said, "let me think a little." As he still looked at me, "Leave me. I am amazed by what I have heard."

He said to me, "Though I leave you I shall be near you; my mind is already strung to your pitch, resounds to your every thought. I shall know whither your thoughts tend." 
I answered, "Though you may I shall be to myself alone. I do not yet feel influenced by your mind, except you, as it were, speak to me."

He closed the light from his face-the expression.

I felt intensely relieved. He gave me a draught and went out. I drank, and, for the first time since I arose from my long sleep, I seemed awake.

\section{CHAPTER II.}

I was alone. Thought-the free motion of the brain-began pleasurably to stir within me. Weir-yes, if I could only see him now. If he could only see me.

I can recollect how the old man's hand trembled as he gave me the last draught. 'Twas my death to him. He knew that a few more years would finish his career, and we had been fast friends so long.

Then-Oh Heaven! with what vigour the new thought rushed in-that centuries had passed, that the deed had been done. The old world was now in the background all the old faces, friends gone.

Yet I lived. Alive. Well. Yes, to see, to know more than I had ever dreamed of.

I had an intense desire to rush abroad, to see the men and women. Glorious, beautiful faces rolled away past me in the stream of imagination. To see-everything. What, I could scarcely conceive.

Yet I would not. I would think first-wait till I heard more.

My companion's talk had made me feel almost like a prisoner. I had pictured to myself ere I slept, that my awakening would be like the crowning of a king; the world would be wondering at it. Yet, now it had come, what was I?

One of those great epochs of time-I might say the second-had passed over the world. The first made man a knowledgeable animal, to know good and evil; the second made him to know not only his conscious self, but also all others around him; to read their thoughts like open books, and that, in sequence, had brought on the dream of past time. THE GOLDEN AGE.

Yes, even though there were still, amid it all, those who wished themselves blotted out of existence.

Surely by this time they should be able to visit the planets-the little group of worlds swimming, not so far away.

What had my companion said? They talked of it; it was not done yet, but then he had not told me all. 
When I recalled his manner I felt a conviction that this also was soon to be accomplished, and then! and there! would we find a nobler race or a wide empty world? Had the creative power chosen this earth alone for its battle-field with the dead inertness of matter? Left the rest of the solar system for our increase, for the increase of those godlike moving beings, where not only dust stood, a symbol of beauty and life, but where to an immense extent, power was transmuted into pleasure?

I saw that though I could not read the mind of my late companion I had been sensibly affected. A semi-knowledge, which was not thought, was wandering through my brain-a dim, beautiful idea of intense mental pleasure, a pleasure which made friends happier than lovers;-and, lovers, can you imagine a sea of glory, a stream of intense moving rapture, yet self-conscious with beautiful calmness and a delicate unfaltering perception? My spirit was wondering at its own imaginations.

'Twere good indeed that this people should reach out to the stars and fill the vacant world with emphatically the Glory of God!

While I was thus thinking a woman opened the door and stood before me.

I was (that is before I slept) about fifty-six years old. I had known women in every form and phase, in my other life. I had lived twelve years with one whose features I yet recall blent with a halo of beauty and kindness; yet this woman swept completely all other thoughts or imaginations, joys, or sorrows, from my heart; her look like that one might bend on some noble yet wounded beast struggling bravely for its life amid pain and partial helplessness. Yet so much more; I felt huge pulses throbbing about my head, of whose existence I had not been before aware.

She came near to me; she stretched out her hand, and as I took it, I seemed to begin to know thousands of events, people's acts-some past, some present-but all indistinct, dim, yet thrilling my heart with exquisite pleasure.

Moved by instinct-for who could think with such a face, such eyes, before them?-impelled by instinct, I say, I moved from off the couch, I know not how, still holding that divine hand, and whether I tried to steal my arm around her, or kiss as I pressed that hand, or whether either went beyond thought-or whether both were madly mixed and produced a strange position, I cannot tell; but what I know is, that that calm, yet intense face looked down on mine, without displeasure, and the words "Not yet," like the tones of a bell fell from her lips. 
I think the rush of thought and pleasure took away all power from me; I sank to the ground, and, with those glorious eyes still bent on mine, she sat beside me.

Then she began to speak in a wondrous voice, whose soft tones, though seemingly restrained to a level nigh monotony, roused my spirit like a song of freedom. During all that low-toned monologue, whose restful words flowed on in unchallenged certainty, my heart seemed to be moving beneath its old fetters-the past life-ready to rise and be one with the present, one in the great onward march to the great future.

"I often saw you sleeping, and read off the half-effaced thoughts of your past life. Long before you awoke, your brain would respond to mine, and tell off, though in a broken manner, all your strongest desires-all your troubled longings; and now, as you begin to see, we know so much of each other, you may speak without fear of myself-of anybody-of others-as man would speak to man, or woman to woman, for we read the thought if we speak not the word, and you must come into this same state of liberty."

Then my heart called out so loudly that she must have anticipated the spoken words: "If I might but follow so fair a guide till I could stand in perfect equality on the great plain of this new life; if I could"-but, ah, my rising spirit fell back as the words-"NOT YET" again dropped alone in my heart, and her clear liquid eye looked so steadily into mine, that it fell back in wonderment.

"Listen," she said, and, in what seemed a secret corner of my heart, the old words "NOT YET" seemed again to rise, and the glimmering spark that flitted in her eyes told me she too heard it. That single word, "Listen!" seemed to be repeated in my spirit till it calmed it. Then the fair, clear voice began anew. "The passions, the varied emotions of our hearts have ever been used to build up the mind and empower the brain. We do not now dismiss or try to conceal our passions. Women are now educated that their feelings may live in their intensest strength, but always in fit place, environed with beautiful circumstances." "No," she said, as answering my thought, "not gold or pearls, and grandeur, but beauty and pleasure of thought and coalescence of spirit, that could live alone in another world for years, and yet not weary."

She rose to go, and my heart strove again to assert itself, and seemed to struggle to grasp some tangible object, to break that impenetrable calm, and extract-if but one word-from her unguarded heart. But, held by the 
spell of her being, it fell back, and, erecting a secret altar within itself, it there poured out its worship.

But not, as I thought, unknown. Even as she passed, a strange smile flitted on her features, and the words "NOT YET' seemed to ring anew over all my heart. A glorious mocking of my secrecy!

\section{CHAPTER III}

She was gone, yet her presence lingered. All the fair beauty of her pure thought, the ideal, the essence of her existence hung like a glamour over me, and, as after the other visit, I began to be aware of many things ere this unknown. While she was with me the full tide of her life seemed poured all about my heart, burying the landmarks of the past, and swallowing up knowledge in emotion. But now, as I grew calmer, facts and incidents sprang up in my brain-knowledge that came as a dream, I knew not how. Were these things true? Or was my amazed soul beside itself? Were these indeed Alfred Malcolm Weir and Edith Weir-brother and sister, and the descendants of my best friend? and had they, while watching over me as sacred dust, read my thoughts? Yes, here at least I could recollect Edith Weir had said as much. Oh, Pride! Ambition! Glory! What are ye all when friendship and trust draw nigh and breathe upon the shipwrecked solitary spirit? Not more does the escaped mariner rejoice in the safety, the warmth, the comfort of the house of refuge, than did my naked soul. It seemed to escape from the perilous exposure, and find in this relationship a cloak, a shelter, a refuge from its pitiless eye of the great world. Ah, yesdid I belong to another age? and was my spirit old, and gnarled, and full of crooked ways? Give me but a vision of that sweet face, and what else in my heart could be seen or known? What of any hatred or malice, or any uncharitableness, even by an eye Almighty? And rising up like little knobs left by the retreating waters, other thoughts appeared.

They, the people of the new world, knew this, and for this reason had that fair face looked so often on my sleeping features, had her strong soul so often tried to wind itself about the convolutions of my half-frozen brain. And, perchance, for this-but, ah! how dim and shadowy grew this imparted knowledge now!-for this she would be ever with me, and all her love be mine, to guide and comfort me, and make my coming life glad as that of those I should dwell among. And though it came from farther than an echo, "faint as the faintest breath on polished stone," it was indeed "a 
chance that would redeem all sorrows.” Pay-ah, doubly pay for all the risk and dangers past. If it might be!

I was walking up and down in my apartment, still filled with my surging thoughts, when the man who first awakened me again came nigh.

I hear a knock at the door; I cry "Come in," and there we stood, with a new sense of relationship, face to face.

"Ah! I see," he said, "what you are thinking of. I am very glad that our relationship gives you some pleasure. 'Tis something like the trust and confidence we have in each other now. But you have not yet seen the outer world. Come."

I followed him outside. We seemed to be in the midst of an immense city. The streets were as thickly peopled as the old London streets, but they were four times their width, and planted with trees along either side. And then the flying machines!-my eyes were ever straying aloft-they were sailing like swallows in the summer afternoon, beautifully shaped, glittering in the light. My companion turned to me. "Yes, they look well. I think we beat the birds now, in command, as well as in pace; but still the old principle holds good. You are in front of the time there."

Of course I accepted this with a graceful bow. But young Weir (for thus I began already to think of my new companion) continued-

"When I look at the sky oftentimes, and think that but for you, we might be yet grovelling on the earth, but for you, horses or men, or cumbrous steam might be yet painfully turning up the hard earth, and reaping the scant harvest, I wonder the world in general does not rise up and give you an ovation-show at least that they are not forgetful of those who thought and worked long ages ago. But here comes Moxton; let me introduce him.”

Then I, John Brenton Hope, almost wished myself asleep again. I did. They looked at each other. I knew they were speaking; but that was not the thing that went into my heart. Up rose before me the woman's face I had seen, Edith Weir. I seemed to hear her name. I saw her-through Moxton's presence.

He looked out so hardly and proudly that minute, as though he would crush remorselessly every weak or unlovely thing, even though it were part of himself-Lucifer, but Lucifer triumphant, and as Byron imagined he would be in that case.

I thought all this and much more in the second of time ere we were made known to each other. Of course the speaking was a condescension to my old-world weakness, which I thought they might almost have 
dispensed with; but was rather taken aback when Moxton said, as if answering me, "It were better."

I looked hard at him, as I had looked through many a man before.

He smiled and said, "I wonder in what manner we are alike?" Then, as I still gazed, "Edith Weir has taken so much of our thoughts."

I answered, "Charles Moxton, I do not quite comprehend all your meaning. I suppose you know all my thoughts. I only know some of yours, and even those seem to obey different laws, to be governed by different instincts to those common to the old world."

Alfred Weir interposed, "Moxton, you and I are the only men Hope has yet conversed with."

Then turning to me, "As soon as you become a little more accomplished in our language of thought you will read the laws of morals and manners in the mind of every one you converse with-not that they are difficult, the negative part is the lack of all you are ashamed of; the positive, as it is used, runs farther with some than with others."

"But what is this?" I said, as a huge building caught my eye, supported on pillars like a temple, but that the spaces between the pillars were filled by huge doors, some of which were open, and some shut. I should not have noticed it, perhaps, but for its being surrounded by a large open space about a quarter of a mile in width.

"Oh, the new shed for goods traffic," said Weir; "let us walk down and see the Aphis start." We passed several of the aerial boats standing on an inner railway, which circled several times round the enclosure.

In shape and fashion these boats were like the old blockade runners, their upper lines being as graceful as those of the hull; in fact, more so, for beneath their symmetry was marred by the wheels on which they ran.

"Yes," said Weir, "if some fellow could get rid of gravitation we could improve their appearance." Then, as if struck with a sudden thought, he said, "I say, Charlie, pitch out that stick of yours."

"All right," said Moxton, with a smile; and he then threw it out twenty yards or so in front of us.

We stopped. The stick rose up and began to come steadily towards usit had a curiously carved head and looked like a species of snake advancing.

Weir began to laugh, then going slowly toward it, motioned with his hands to push it back. It was absurd to see the head thrown back by every 
pass he made; yet, despite his efforts, it still made way, Moxton standing with just a touch of Lucifer on his countenance.

"Oh, come on," said Weir, as he came back to us, and the stick resumed its original motion; but suddenly it was dashed to the ground as by a gunshot. We both of us felt a slight shock.

I simply looked round, but Weir exclaimed, "I say, Moxton, you are getting as strong as a battery."

Moxton did not answer him, but seemed to be concentrating his energies. He said, "Now look."

The stick rose with its point in the air, then, dashing that to the ground, it came with a bound like a tumbler right into his hand.

"Oh Lord, Moxton," said Weir, as he took the stick and began facetiously to examine its head, "its eyes are growing, it will begin to eat next week; look," he said, handing it to me.

"Is it a trick?" I asked.

"No," answered Moxton, "magnetic power of no practical use at present. Try it, Weir. That stick," he said, as he handed it to Weir, "it is like an old violin, constant use has made it more easy to be penetrated by the magnetic power."

"But," I said, "we both felt the shock when you dashed it down."

"Yes," he replied with a smile, "all that you feel was dissipated, lost. But don't be a fool, Weir."

For Alfred Weir, after several vain attempts, had induced the inanimate bit of timber to follow him, retreating with his face still towards it, and giving it, as far as he was able, the motions of a frolicsome drunkard. Hearing Moxton's words, he brought it to grief on a rail in front of us, letting it lie, but I noticed it rose up by instinct into Moxton's hand as we walked over it.

"Here comes the Aphis," said Weir, as one of the huge doors rolled up and a beautiful, almost steel-blue vessel came slowly out.

"She is one of the largest yet built," said Moxton, as four immense pinions pushed themselves out from each side of the vessel. They shook the air for an instant with a tremulous motion, then poised themselves as the Aphis slowly glided off on an outside track, which I could now see running round the enclosure. The wings remained poised, but the vessel's speed increased continually, so that ere she had travelled a mile she must have been going at the rate of a hundred miles per hour. As she again neared us, I saw her wings moving again faster and faster till the points 
faded from sight, and the whole pinion resolved itself into a flutter of air close to her body. Then she lifted herself steadily upwards, propelled forward as yet by her attained motion.

"Now she has her full swing," said Moxton, as the vibratory motion at her sides seemed suddenly to lengthen, and, even at our distance, we could see her dash forward with an immense accession of speed.

"You could almost visit a planet in a boat like that," said Moxton. "Yes," answered Weir, "that is what I proposed, but Moxton is afraid we should use him up as motive power if anything broke down or wore out. The only reason, I assure you, that kept us from starting."

Moxton observed, in a "to-those-whom-it-may-concern-manner," that Weir always made bad jokes when hungry.

\section{CHAPTER IV.}

So their minds are not always strung up to that intense height of thought. A decided feeling of relief, of relaxation, had been stealing over me during the walk; the childlike fun of my friends seemed to give me more assurance than I could have gathered even from a perfect knowledge of their thoughts. The only thing that disconcerted me was Moxton saying, with his eyes "Yes, men play now, and children think."

I had enough wit left, however, to say in the same manner, "Then, to which class do you belong?"

"We are as yet betwixt either."

And I knew there were further thoughts in his mind, which, perhaps, he did not intend me to catch, of how I was standing betwixt the old and the new, and, though living in the new world, only half its child. Half pained, my eyes strayed to Alfred Weir; there, too, the same strain of thought was playing. The face that looked on mine as when I first wakened.

Moxton broke up the reverie, "Suppose we go for your sister, Weir, and you dine with me?"

We agreed; and, hailing a carriage, we rolled swiftly away to the outskirts of the city.

What a brightness seemed to infuse itself around us with her presenceeach heavy thought, each hard, out-stretching idea, was put far away, a sweet pure stream of bright ideas, interspersed with words, musical and beautiful. And, though she gave by far the larger part of her attention to Moxton, there was what may be best described as a steady current of 
serenity flowing continually from her head to mine, and again I was aware that my appreciation of it heightened her enjoyment.

But if Edith Weir shed light around her, Lucy Moxton seemed to bring us into the region of sunshine; like the angels of life and death. When her brother introduced her to me, he, dark and tall, with every motion indicating power, her beautiful hair and sunlit face-yet, no, not life and death, but love and death-for Edith Weir was yet the embodiment of life to me, my guiding star.

I sat beside Lucy Moxton during that long and happy dinner hour, drinking in her flowing, bubbling thoughts, and rejoicing in her happy laughter.

"The old world was not so bad if all the men were like you."

I could not but rejoin, "The new world was indeed a paradise if all the women were"-but I did not even in thought conclude the sentence, and she knew the "you" was inclusive.

I described to her John Malcolm Weir and Wilsdon Moxton, whom I had known, ah, far better than I knew her brother and Alfred Weir.

The summer evening air stole in through the long open window. The level sunshine seemed to be caught and broken in the rustling leaves; to be born in to us among the faint sounds they awakened, and to mingle with the fine pleasure that, like an atmosphere, enveloped us.

As I look back on this time through the halo of time and the immense distances of space, on the old, new world, thronging with its almost glorious inhabitants, I wonder and try to forecast the future, my thoughts circling out in wider ranges, till the life of the universe and the mastery of creative power seemed only akin to the distant circling system, and almost within our grasp.

That was a strange evening. I remember walking out into the fairy-like garden with Lucy Moxton, while she told me some of the many incidents that passed in my sleep-how many had at first gazed at me; how unwise imitators had fallen through to the unawaking sleep; how it had been made criminal to give the draught of sleep; the names of great men; the coalescence of nations, the final triumph of sense over brute force; till in a soft, low voice, how Edith Weir with herself had watched the living relic of the past, and tried to read the last thoughts imprinted on the brain, of which, by the way, she startled me by saying "We formed a chart, which I will show you some day". She repeated what I knew so well, of the affinity which they had discovered between the mind of Edith and my own, and 
then I remember walking in the holy twilight, the dim, beautiful glow, till the face of my companion seemed to be fading in the long distance, the darkness to creep into my brain. I seemed to feel it numbly as a noiseless prelude to death, and only saw among it, like a star, the face of Edith; then it closed over me.

\section{CHAPTER $V$.}

But with the breaking day again came the full tide of sensation. 'Twas not so much the body as the brain, the press of ideas, the tide of thought, and then, perhaps, it was but that the meats and wines were not such as we used two hundred years ago.

Yet even as I became conscious, almost at once I heard a chorus of voices, and down the street came chaunting a troop of girls. In the clear morning air, in the delicious breeze-had I slept, and dreamed of yesterday? Had I awakened a thousand years back in this world's history? Such beautiful youth seemed not to belong to dreams of philosophy and the latter days. Yet they did. And many a morning since have I hovered in my aerial boat over the great city, and seen the troops of men and maidens, who would sing as they passed to their labours, strong and joyous with an intense vigour, that only required restraint. For, as I quickly saw, a few years' work in the early years of life sufficed to keep the world full and plenteous of all store, and many wrought on, some for pleasure, some ambition, and some for gain. And, though millions thronged the vast pleasure-grounds of Europe, and cities grew out like countries, there was enough, plenty, and as provision for inclement seasons, such immense stores that never were dreamt of in other days; but this is all what I saw and gathered later, and when rolling over the fertile plains of Africa, or watching the Amazon with its myriad streams.

I was for an hour with Edith that morning. She told me much concerning the social welfare of that day. She said, "You do not seem quite to understand that law and ceremony and promise are hardly needed now. Should a man deceive a woman not one in all these throngs you see would speak to him, whilst she would receive daily comfort; then each one marries young."

It was strange to see the frank smile which made the blush pleasurable as the young girl told me of all these things.

"But do you take one another for better or worse, richer or poorer?" She knew the rest, and said with a smile that seemed to becalm my brain, 
"Sometimes. The struggle for existence is really ended, and so much sweetness fills every relation of life, that the old sins and sorrows are gone; except"-she stopped. The first cloud I had seen swept over her brow"there are some like the monks and nuns of old. They are not closed in by walls or pointed out by garments; they wander among the crowd; but they are bound by the voice of the world. They have no interest in the future, nor could they hardly wish to perpetuate their own existence."

Then I said to her, "This opening of the gates of thought has not swept away all weakness or unworthiness."

She looked one of those strange looks. "Do you understand impossibility? Can thought give you six fingers, or take away an inherited disease or deformity?" But she continued, "They have pleasure to the full, and though they have sympathy from the rest of the world, they oftener draw together. Their joy is wilder, but it seems to us like that of a drunkard."

It was with us, then, like Danty's lovers, when they ceased to read of the loves of Launcelot and the Queen. "Our eyes oftentimes grew together." Could it be possible that we should simply clasp hands and she would be mine-but she went away with a laugh, seeming to fling back on me a shower of thoughts- of stolen waters-and old world gallantries.

Then she came back and looked at me till a thin, freezing fear crept like despair around my heart. As I looked on her glorious form and triumphant features, the thought of my own meagre body and my face like that of one of those who are not fit for the battle of life, filled all my mind; but she came and gave me her hand as she had done when first [I] awakened, and then I doubly knew and felt and believed all her goodness, and in her thoughts I read that had the social decree doomed me to remain with the things of the past, doomed me never to mingle my own life with present and future, then other than her brother would have met me wakening, other than herself would have gazed on me sleeping. Yes, I was content.

"But did no one break these unwritten laws?"

"But rarely, and then they are put out of the commonwealth and live amongst those nations not yet incorporated in the kingdom of thought, the Hottentot, the degraded Negro, and the great border land of peoples."

"And are there many of these?"

"Yes, in numbers, but in proportion we are ten to one, and soon shall be a hundred." 
As I talked with her, she seemed not so much the glorious creature of the new world, but a maiden with a strong, true mind, in whose love one could be-oh, how wonderfully-at rest, for before the morning was far gone, her brother and Moxton came for me.

\section{CHAPTER VI.}

The fertile brain-the power to do next only to the power to be; that which guided the world a thousand years ago would guide it now. Were Shakespeare or Darwin now alive, still striding before the mass of humanity, their great minds would cast into farther recesses the rays of human knowledge. So I thought on the eventful morning-not yet a year above ground, for I seemed truly to be alive again, and was I-I-once again to launch the world into another cycle of progress? Or was it madness? Should we go wandering on in the pathless places of eternity? Should we meet the God of the Universe as we went out between the planets? Wonderful-more wonderful than were the present men and women to me and my eventful awakening. Then a host of details intruded-the expansive force of an atmosphere when in space; the greatest time we would supply ourselves with oxygen-down to the number of revolutions our winged wheels would make in space; and whether it would be safe to use the Yankee Eternal Lubricator-or yet again-would she follow me to this new world, or had I had my day, the greatest reward this world could offer, and now its vastest tomb?

I thought of the happy hours, those dumb, unspeakably doubly sweet moments, that had swept over us, when we drained to its dregs the cup of pleasure, and her hand seemed ever to fill it again. I longed for the old ties, even the prejudice, that would have bound her to me for good or ill. Yes, I longed passionately to return again to the old delicious bondage.

Yes, we all know it, this old longing for childhood's day again. Anything to be at rest, when tired with the upward struggle-and the upward struggle with me had been long. Yet could I be so selfish as to wish even for a moment that she should share the danger, the hardships of the first planetary voyage?

But why delay the coming moment? Three of us, Charles Moxton, Weir, and myself, were soon to start on that most eventful voyage.

John Weir, the father of the [first] man I saw when awakened, came in to see me in the evening. 
"Well, Hope, you are a fool," he said. "When there are hundreds of useless, dull-brained animals whose loss would be no detriment to anything, you must go and immolate yourself before the golden idol of fame."

I reminded John Weir that I had once before done the same thing, and had arisen like a phoenix.

"Yes," he replied complacently, "death is fire, a whirlpool which sucks in all, but gives it not back.

There is an old legend of Schyler's, of the youth who plunged into the whirlpool for the golden cup of the king. He came back again with the cup, but when he attempted the feat a second time-"

"I know," I said, "but I thought it was your opinion that nature should take her course, and that we old world inhabitants should make room for the younger race."

"Yes," he said, "that is it, that is what you are struggling for. You are afraid to let nature take its course, you are strengthening your body with the perpetual elixir, forgetting the terrible struggle that may come on between life and death, forgetting even your disadvantages of form and face when compared with the present race, hoping to give yourself a right to perpetual life, hoping I know not what, some wild dream of founding another world in the distant planets, taking your own genius and two or three of the first men amongst us to certain destruction."

I looked at John Weir, and innumerable thoughts came crowding over me-weird, vague, intense, yet so thick, so fantastic, that I myself could not assimilate them.

"Yes," I repeated in my own mind, "even your form and face proclaim your disadvantage with the present race." I knew well he was thinking of his son and daughter, but not more vividly were their faces engraved on his memory than on my mind.

We sat and thought against each other. I of those men and women whose younger life I loved so well, whose aspirations seemed to touch a perpetual fountain in my breast, of the vast outlook of the future, the intense joys of which the human heart is capable; but during all the time I was aware of the strong counter-current of idea. The strong noble mind which willingly, firmly, resigned its entirety, satisfied to cease to be. The gravity in all its beauty which lingered so long in the features of the sphinx, and seemed to live anew in Grecian art, settled down on John Weir's countenance, as the full force of the idea swept from him to me. Then the 
thought rose up and seemed to cry aloud within me, as in revolt from the known sentence of his law.

It was but an hour ago and your greatest wish was peace and perfect rest.

What a grim, powerful smile illumining the old man's features as in his eyes this but weak thought like a crying child arose.

Yes, you allow yourself to be flattered by your own mind, the wish for certain life and pleasure is put in the balance against the strength to resign all and yet be calm, and not self-complacent.

I felt beaten back like one who would leave a desolate island, yet wave after wave leaves him exhausted on the beach. Yet even in the moment, something-that unknown power which rises up with a resistless energy and assures us of victory-awoke and began to move. I felt the light break on my face and fall into the old man's eyes, before ever articulate thoughts were formed.

To leave this greatest act to dull-brained fools, and my own thoughts to be wrought out by a stranger; to wait at home and count death; to send out on the wildest and furthest voyage ever dreamt of by man, those men of the present whose later birth had brought them nearer to the eternal harmonies.

Yes, John Weir, though heaven and earth be now against me, I will see through my latest and brightest thought. I know the future will be for me, and if in yon world afar I can attain that endless being, which the present race seem to think me unfitted for, who, even in thought, can there render me aught but homage.

"Yes yes, so far 'tis well. 'Tis a noble thing for the caterpillar to live all through the summer, but can he refrain from envying the butterfly?"

And as he left, the looks of the girl and her father were mingled together in my spirit. I thought of the hour when first watched by those eyes that looked too deeply into mine. I saw, as in a dream through the countless ages, the eternal warfare of matter with spirit, the intensity of impossibility, and again I wished I had never awakened.

\section{CHAPTER VII.}

We had sped around the world, across oceans and continents, we had wandered away into space till the world looked dim and luminous. We had performed the greatest feat of the age, we had voyaged round the Earth's 
only satellite-ours was not the first, nor had ours like the others been only fraught with barren honour as we sailed slowly round that miniature globe, whose frost and sunshine and lifeless air we could not for a moment breathe, or live in.

All our thoughts were turned to the future, to our great attempt-not an empty feat, but the opening of a new world-bringing another planet beneath the sway of human intellect, perhaps to find another form of godgifted life. Beings who were not human, yet-yet-yes, what could they be in form and feature? I-Moxton and Weir-for five months we should be rushing through space-a second ark. Would it carry life to another world? Should we reach Venus, I had intended to stay while Moxton and Weir returned. Not that I wished-as old John Weir had hinted-to bring a second time the golden cup of life from the whirlpool of the unknown. We had each and all volunteered, and I was chosen-. My two comrades would return. Then Weir would lead the second voyage and were it practicable Edith and Lucy Moxton would come with others. The boats for the second voyage now were far advanced, ere the first one left the earth.

Our greatest danger lay in the meteors. The principal streams that circulated round the world were pretty well known, but should all that immense space be strewn with them, 'twould add another danger. We had established an intense magnetic current in the Star Climber-for that was her name-so that any metallic aerolite would so affect our boat and be, unless very large, so affected itself, that a collision was at all events placed farther off. Thus, if you raised the Star Climber steadily on her third pair of pinions, or hovers, as they were named-say with her head to the northshe would spring backward at the rate of fifty miles an hour. Stop her and turn her round she would be at the North Pole in twelve hours. This, however, was nothing to our intense motive power. Fancy a humming bird five hundred feet long of burnished silvered steel. You may then begin to comprehend what the Star Climber was like. She was truly a glorious boat. Her main pinions ninety feet long, whose slowest motion was after the first five seconds invisible, whose fine steel feathered points and edges, though more delicate than the most fragile fan, could not even be bent by the human hand, yet such was their flexibility and temper, that the last ten feet, the real pinion, was packed in a box scarce double the old fashion pillbox.

We never expected to use a hundredth part of our power. Once into space, our acquired motion would not need augmenting till we came 
within the attraction of some other planet. Yet here lay our danger: we might perish miserably on some large but airless planet as the mad voyagers De Reef and Frenzy did on the moon. In vain their wings fanned the resistless air. They could spring from the ground, their momentum carried them a few hundred yards upwards, then slowly the gravitation of the little orb drew them back. The thin air was poisoned for them. With a third part admixed they could scarcely breathe; with all their powers exerted they just hovered; the meagre atmosphere did not extend three hundred yards, in that they could move, although but slowly, after once losing their acquired momentum. But of that they could not rise.

The wreck lies yet in one of the deep craters in the North Eastern Hollow. There, with their patent air suppliers they walked out, trying to find material to re-supply their oxygen; and had they been as clever as they were daring I believe they could have existed for months; but with little practical knowledge, they soon saw their helplessness, and ceased to strive. Moxton was with the party who found and buried them, and he took us down to see the place.

"A grave in the moon," with a huge natural tombstone of black rock above it, and deeply engraved their names and cause of death.

Moxton said he thought for our benefit, as he never saw anyone wandering about there, and although we were sure of an atmosphere in Venus, there might be many unknown causes to drive us out from the new world.

Our offensive powers were certainly enormous. A cannon or mortar was almost built into the vessel, yet swivel-working with patent discharge, so that with its mouth in space it could pour forth such an incessant stream of fierce projectiles as might frighten the boldest adversary, it was also intended to use also against any small mass we might meet with in space, and last, but not least, as a motive power if we needed it; its range was between fifty and a hundred miles, and the explosive strength of the projectile only limited by its proximity of the enemy to ourselves.

Moxton used to say he could dissipate the moon if it was worth while, but as that would have necessitated an aërial snagging contract, or made still more unsafe the interstellar way, we persuaded him to turn his thoughts to other fields, and let our little satellite still go on its way rejoicing.

We were very happy that last week, I and Edith. Her brother had wild spirits-his caricatures of our party, in which I and Moxton figured 
conspicuously, were, as he used to say, "If not heart rending, spirit shaking."

"The Star Climber wildly diving through blue ice for some unattainable South Pole, while Moxton and I with feet firmly planted were holding her by the rudder."

"Moxton succumbed to Venusian wiles, a fish-like maiden combing his hair-a man-fish, grim, in the distance."

"Seven years after, John B. Hope, very seedy, twenty-four young halffish, assorted sizes, two flabby creatures in the rear, he sings dolefully 'Home, Sweet Home."'

\section{CHAPTER VIII.}

As the planets roll in space, as the world turns its varied features to day and to night, with insensible motion, and as the solar system is swiftly moving in its predestinated course, noiselessly, silently, without even a rush of air around, so when our little bark shot into space, the noise, the throng, the sea of faces were gone. The fleet of air boats which hovered about us so long fell off one by one. We were alone.

Then the throb of our machinery was silenced. We had left the attraction of the world, had become as it were, an independent atom of the universe, had joined the grand march in the old world heavens, could see our natal world, now an orb, hung in the air.

We all knew the sensation-this loss of gravitation-this general unstability-this strange silentness, had felt it before. Yet it now seemed to quadruple its force. Perhaps it was the thought of danger, the knowledge, the realisation of how much-well nigh certain life and happiness-we were leaving behind, were risking for the air-bubble of fame, futurity. Yet this did not last long. We wished afterwards it had held us longer. Our brains were tired with the inevitable inactivity. We were forced to take refuge in work before the first incident broke the monotony of our journey.

One of us was always in our watch tower, with an intense electric light ready to turn in any direction, piercing for miles and miles the wonderful half-lit purple gloom that enveloped us-the gloom that was not darkness, yet want of light. We could see both the sun and stars shining, yet it was not light. The want of something to catch and stay those arrowy beams made the realms of space seem dim to us. 
This was the thirtieth day of our journey. So far everything had prospered-all our machinery worked beautifully. An even temperature, which did not vary, except at our pleasure; our supply of air equal to that of a new country, and our speed, as we found from observations, had not slacked since the second day we left the earth, or since we had been entirely free from its attraction. We had met no meteor, no aëreolite had dashed across our way, both our offensive and defensive instruments were as when we parted from our last friends, and all our munitions of war were as yet in full stock. But this day, as I looked out of our watch tower, I saw right ahead of us, an increase in the darkness-an aërial fog bank-a Magellan cloud; and as we got nearer it stretched away farther than the eye could see on every side. We then threw forward the intensest light of our electric lamp. Its rays seemed to touch it and stop, yet we knew from a variety of tests, it (the Magellan cloud) had no substance-not the least attractive power, and though earlier we could have avoided this hugedevil, Moxton called it; and, as we afterwards found it-canker in the universe; this death of matter, as death here is the death of life; this unutterable thing, which dissolved all things, everything-not into their original atoms, but into itself, into vacuity, nothingness. We could have avoided it-but before we had made up our minds, the intense speed of our noble boat carried us into its midst. No ray of light pierced it-a sense of unnerving fear swept over us and vibrated from soul to soul as we found ourselves in this unknown thing.

Moxton was the first to recover himself. He quickly took our instrument provided for the purpose of testing the exterior air, which could be thrust out as you push out a telescope, then opened, enclosed a small sample of the atmosphere and could be withdrawn. This Moxton did and detaching it, placed it in a glass vacuum chamber, and opened it. But what was our surprise and horror to see a small black patch float out into the receiver. It was then Moxton gave it the name. "It's a bit of that old-fashioned thing," he said, "the devil." But his eyes were not, as ours, on the curious little black cloud, but on the outside of the instrument in which he had caught it. His strong thought dragged our eyes there too;-although it had been exposed but a few seconds to this infernal gloom, it was cankered, its polished surface dulled and roughened. We drew down part of our signal staff, which was also of polished steel. Into it also this infernal atmosphere was marauding, and we comprehended in an instant our awful danger, for the whole exterior of our beautiful boat must be in the same manner 
disintegrating. This unreal blackness must be feeding among all her delicate wings, weakening each minute her glorious frame. Quicker than any word could be spoken we all knew our best course-our only hope. Moxton opened the box in which lay the springs of our defensive powers. "Hold on," he said, then laid his hands on the springs of our defensive organs. Though prepared for the effect, the rebound that in this thin air would drive us so fiercely onward, and gripping [what] was within our reach, both Weir and I were thrown well nigh the length of the cabin. The constant and enduring recoil of the perpetual discharge trebly accelerated the Star Climber's speed, and although she weighed, say a hundred tons, there was absolutely nothing to stop her. For ten minutes did the smoking stream of fire and noise bellow through, and fight in this horrible spacethen Moxton again touched the handles, and the voice of our deliverer ceased. The speed we had attained must be frightful yet the hideous darkness was yet around us. The minutes seemed hours, for we knew we were going faster than a shot from a gun, then at the same second the same thought penetrated us. I sprang to our lookout tower, closing down the outer casement, made haste to disconnect one of the glasses, while Moxton turned to our stores for a new one. But Weir, though later in thought, was quicker in action. With a turn of a handle, which was close to us, he sent the electric current through our outside signal lamp, and as the light came back, blurred and faint through our roughened half-decayed windows, we knew we were out of that horrible gloom, for as we entered it Weir had tried this same lamp, but then not one of those glorious vibrations had come back, all had been quenched by that enemy of nature and life.

We adjusted the new glass, threw back the outer casement, and there, behind us, lay the horror we had passed through-a black fog bank stretching away on either side farther than the eye could reach, and in height and depth it filled from Zenith to Nadir the purple Heavens.

This starlit gloom, this mock sunshine seemed now like a home, we rejoiced and felt safe in it; but, before anything else, we must make exact observations and know our rate of speed; also how much we should need to alter our course, for we were not rushing on to a fixed spot, to an oasis in the desert of the heavens, but to a wandering star that was here and there, or still farther on, according to the hour at which you sought it. We could not rush madly on, or we should reach the place appointed weeks before the planet spun its immense mass thither. It was a long and anxious 
time ere we could say with certainty we were again right, and fix the precise hour and spot of our meeting ground.

\section{CHAPTER IX}

At last it was done. We knew our position, had replenished our instruments, and ascertained as far as possible the damage done to the exterior our gallant craft. We had spread out her silvery wings, and though their beauty was gone, they were practically uninjured. In the air of the planet we had left I think we could even now go near to five thousand miles per hour, although their delicate edges were frayed and ragged, just as if we had been in a bath of some strong acid for ten minutes.

As for our appearance, it must surely be something like Coleridge's idea of the "Ancient Mariner's" bark. If our sails were not, our wings certainly were "thin and sere;" and should we again re-visit the glimpses of our natal moon we might startle more than "the pilot and the pilot's boy."

We were all thinking of our past danger, Moxton keeping his watch, gazing into the infinite space before him. He suddenly began to give us the moral of our last danger and escape. "There seems to be no limit to the speed we might attain in space, and if so, then distance becomes annihilated, and the whole universe open to us. There are other suns, and doubtless around them systems of planets such as we find here, but"-here he turned sharply round, "let us examine our friend the devil." Intimating in this coarse manner his wish to try some experiments on our little black genii-the handful of cloud we had fortunately secured.

We spent some little time in finding its specific gravity, or in trying tobut as we might have guessed, like the element it floated in, it was lighter than the lightest gas. We introduced a little common air, and soon observed a faint brown envelope all over the black mass, and by the aid of our instruments a slight sound between crackling and frizzling, evidently some chemical action going on.

After confining our friend in a still smaller compass we took from our small stock of living creatures a mouse and introduced it; we might as well have put it into a bath of prussic acid-its death was instantaneous. The effect on it being much the same as though it had been put through a flame.

To think of a world, like the one we had left, plunging into such a mass as it came rushing through space. A garden of Eden-a desolate wilderness 
would be nothing to the brightness and beauty and life before, the canker eaten blackness, the universal death behind. There would be no time for thought; like a black fogbank it would loom-then sweep over all with awful swiftness-and amid unutterable darkness the stinging vapour would lap everything to its destruction-and presently the world would ride forth to the outer day with its load of lifelessness - and creative work must begin anew.

"But," said Moxton, "perhaps the envelope of air would protect the planet, and all this destruction be reduced to a frizzling match some miles above us-in which the ancient deities ought to be more interested than the mundane inhabitant. All this, however, our little friend would probably enable us to find out-like the witches of old and all other scions of wickedness, when caught. A lively time would be in store.”

And we, like an earlier-aged pilgrim, went on our way rejoicing-having, we believed, escaped from our Giant Despair, nearing we hoped, a better country.

Weir said, "Suppose we find the angels there."

Moxton, "Suppose it is inhabited."

I answered, "In that case most of our hopes will be disappointed. We must seek another planet-for over earth's over-crowded happinessperhaps before our search is ended it will lead us even to another system."

"Yes," answered Weir, "if we return from this first journey."

For the great globe of Venus was daily growing huger before us, like a moon at three-quarter's full it now appeared-yet not so clear as the earth's attendant; with our strongest glasses we could see both mountain, plain, and water; clouds, too, sometimes could be distinguished, altering the appearance of whole tracts of country, and making us doubt our geography.

Our spirits grew buoyant, and a strange hope uplifted us day by day, that our enterprise would be successful. I think we began now to realise "the wonder of our work." Day had followed day with such unenviable calmness, as we walked up and down our gangway, but there was always an undercurrent; whispering is it a reality, or but a dream, are you in the Star Climber amidst boundless space, or are those centuries of sleep unfinished, and are the dreams in that long night so real, John Bredford Hope.

Moxton and Weir knew all this-far more satisfactorily than I could gather their thoughts. 
Moxton said to me, "You do not lose much-we are fuller of ideas than thought; our minds are like new wine strong and fiery, they want the glamour of age-the charm of long experience."

So we sped on, piercing the boundless, trackless space, that long purple gloom, where day follows day, and night, night, all wrapped in the same cold sunshine. Since the eternal ages dawned and the vast matter of this universe was gathered into orbs, those same swift vibrations had rushed through the thin air carrying heat and life to the bounds of the system.

And were it possible that other vibrations could travel swifter even than the beams of the sun, unseen yet no less real, I might have said that from the old world streamed a sweet influence. How well I remember it, as if some archangel had poured out a vial of sweet peace over my troubled heart. The influence wrapped and crept like the thickening mist of evening around my spirit, and that night, as Moxton and Weir slept, was, and is, one of the sweetest I ever lived.

Edith seemed to be always near me in her every beauty, sweeping all thought and care from the troubled brain, and when that influence faded like the red in the sunset, an intense peace seemed left. Such a mind as one would wish the spirit to possess when it quits this body of life, that whether, like a seed cast off from the tree of Humanity to find a rooting place in some other matter; or to be wafted, perhaps, on the ocean of infinity through long ages, till it drift ashore in some other world, and began again to mould the material by that, which, to our sense, is not, or like a spark it flitted out in darkness.

The old past days my earliest life all revived and ran through my brain; but not in wild disorder, the influence in which they moved never waned, not even the monotonous morning could affect it, though, instead of clouds and dew and rising light and shadow and mists and an awakening world, the same dreary night light poured its unvarying sunshine over us, the monotonous air all about us, and around the nicely finished interior of the Star Climber.

Weir kicked it the other day, wished for a toothache, said that pain would come to be considered an epicureism, a dainty, a mental olive. Then sat down and calculated that for more than two full days we should have to career around our destined landing place. Skimming the thin air-most likely diving in and out of the atmosphere-getting rid as fast as we could of our superabundant speed. This was largely owing to our friend of whom we bottled a portion. 
"But even then," Moxton said, "we should be large gainers. Our increased sp[eed] having saved us some hundreds of hours, and as yet given no larger risk."

In truth we had not sighted or felt a meteor-the chances of meeting one seemed less than that of a collision between the water going ships on the ocean.

\section{CHAPTER X.}

We were old travellers. We knew the heavenly way; we had ere this left the attraction of our native orb; we had seen with wondering eyes another world growing out and becoming immense before us, till it suddenly filled the whole horizon. We had heard the sharp sounds of the first thin air as we rushed through it, but that experience did not quiet our beating hearts, as we eagerly watched for the critical moment, when we must check that headlong plunge which our vessel would appear to make as the huge force of gravity again enfolded us.

We were fully conscious of, yet not able to realise the intense speed of our vessel. The pace at which we left the earth might be roughly estimated at twenty miles per second, not that we moved at that enormous speed in the earth, but we entered space, not only with our proper motion, but with that of the world we left added-viz, that mighty speed which annually brings winter and summer, and carries the earth and all its inhabitants some six hundred millions of miles in the year, and its smaller, yet not despicable diurnal motion, which might be roughly estimated at a thousand miles per hour. Of both these motions we were enabled by the course we chose to take the largest possible advantage, thus we were not laggards, even by comparison, with the giant orbs we were among. Then our adventure in the Magellan Cloud had superadded to that enormous speed another speed which we computed to be equal to a third of that already attained.

We could not, as I said, realise this intense velocity so far beyond any terrestrial speed-even that of the ball as it leaves the cannon's mouth. Yet the knowledge of it made us doubly watchful to catch the first sign of an atmosphere, for should we continue this course uninterrupted-like a comet or falling star-we should blaze up, and either drop on the new world a blot of molten steel, or be whirled away, blasted and burnt up on a wild comet-like track-to form, perchance, a study for some latter day 
Venusian astronomer, as our erratic orbit brought us again and again within his ken.

When journeying between the earth and moon none of this fierce speed troubled us, the distance in itself so small (but a two hours' journey at our present pace), and the fact that the speed of the moon in its orbit is the same as that of the earth's diurnal motion had greatly helped us.

This new world, too, possessed a moon, but not such a one as accompanied the earth-smaller, held by a shorter chain, and moving across the diurnal motion of the planet, while its speed was very large; it would form a curious study to a gazer on the surface of the new world.

We resolved, however, to make, if possible, some use of it, for we dreaded the many days which we should need to consume ere we could sufficiently check our headlong career, to venture into the denser air of Venus.

By creating for ourselves a temporary orbit, which should at first graze, as it were, the exterior of both orbs (viz.-Venus and its attendant moon) and afterwards gradually lessen till it was altogether included in the atmosphere of the planet, we reckoned to bring all the powers of gravitation into play, and make of them a more effectual brake than could be obtained in any other way.

Also, by bringing our course into the same plane as that of the moon, we should be able to examine it as we passed over and by it. Indeed, we reckoned that the completion of the second circle of this orbit would bring down our speed to that of the lesser orb.

But all this while we were swiftly nearing our destination; the great globe of Venus, in apparent size far beyond that of the earthly moon, now began to grow fast upon us.

It came-that wished-for sound, like the noise of far-off wings, or the whisper of a zephyr; but thus only for a while, like a nearing cataract or coming storm it grew upon us.

Then the mighty wings of our vessel began to play, beating swiftly the thickening air, and driving us fast upward again into space, but not before a great glow of heat pervaded all the ship, growing every moment stronger, though we had now left the thicker air. "Start the cold air machine," said Moxton, "or there will be no end to this business." This soon assisted us, though the heat gathered by the steel exterior of our vessel still continued to strike inward. We were again in the depths of space borne by our own velocity, with nothing to retard, nothing to guide us. Weir, who was on the 
look-out, already beginning to abuse the Venusian moon, when we caught sight of it. Beautiful indeed had Moxton calculated our course; we could see it like a huge ball spinning in the shadow of the planet away before us. Our course would take us very near it; we were, perhaps, two hours ere we came to it. Then there came a sudden roar, a huge swerve of our vessel, as under its influence we shot in again to the planet. Again we repeated the experiment, although I now had the command, and Moxton in the lookout. "Keep her in it," they both said, and we dipped down so close as well nigh to touch the feathery clouds; this was enough for us all; the heat we subsisted in for the next hour would have fairly cooked any dead substance. But as we got clear again and began to cool, we saw what an immense part of our speed we had lost, we were well satisfied with the effects of our purgatorial discipline. Now, although we were sailing in a smaller circuit, we almost failed to catch again the moon.

We seemed to creep on the little satellite but inch by inch. At last, however, we drew near, helped on by its attraction as we approached it; so small was it that when it looked like terra firma, we could observe its rotundity. We seemed to be floating, floating towards it on our back. It seemed at one time as though we should have to use our explosives to prevent our vessel being cast on her back on this airless little orb-an accident we certainly had never calculated on.

But at last we caught the welcome sound; then she heeled over, and we floated silently down on to a smooth sandy plain.

We took in a specimen of the air, it was thin and poor; scarcely sufficient to sustain the lowest forms of life, and the orb itself looked cold, dry, bare, and grey, a few meagre lichens being the only visible living things.

We prepared to strike off again, for there, hanging above us, as though it might suddenly fall and crush us into oblivion, hung the great planet, half in sunshine, half in shadow, covering a third of the sky, hanging right over our heads its clouds and waters, mountains and forests, spread out in wonderful state above us.

We would not lose time on this useless orb, so alike that it might have served as a prototype for the attendant of our own earth. We were growing familiar with new spheres, and our familiarity was working to its proverbial end.

We thought far more of our vessel than of the orb when, like a living creature, she reared herself as a tower on the plain. But as we wished to 
lose as much of the speed of this satellite as we could, we pointed her back towards the way she came; then gathering her power, and throwing it into a sudden and continued motion of her wings, and, opening the thunder of her artillery, she sprang away, and rushed upwards to the larger world.

For a little while we could see our rushing speed; then the little moon seemed to be leaving us, and we to be hanging out in space.

For hours we were thus, and well pleased to be so, as the passing time told plainly of the speed parted with. The planet now beneath us - for the instinct of gravity soon changed as we left the moon-was in its revolutions, bringing another face to our view, and we only needed that as we extended the air again we should bring our course into unison with the planet's diurnal motion, to reduce our speed to an earthly measure.

Once more it came-the rush of air growing to a thunderous roar; and we must steer upwards and outwards, but not afar; still, though the seas and mountains fled away beneath us, we were able to keep within the higher atmosphere, and ever and anon to take a dip into the region of the clouds.

We were weary with watching and waiting-tired, yet determined to endure to the end of our journey ere we slept. The gallant speed and the great plunging dips which our vessel made grew monotonous to us. Below us lay a sea-well nigh an ocean. Moxton took from our stores a large electric ball, which could be discharged from a cannon and would burn with an intense light for some time afterwards. He pointed it straight down and discharged it into the ocean beneath us, we saw it strike the water and plough through the blue depths for a mile or more, then lay like a drowned sun beneath us.

“That will do," said Moxton. "Shall I take the helm?"

It was given him, and under his hands the vessel made a short turn, then with her wings set to catch the air she rushed downwards. It was a terrific plunge-perhaps seven miles as we came, but we knew our strength. How beautifully our wings closed in ere we touched the blue element! A heavy blow, a prolonged hiss and we were careering beneath the waves, but well did the elastic liquid do its work. Under the facile hand of Moxton, the Star Climber was already returning on her own tracks, coming nearer the dimly-lit surface and circling around in a comparatively small space.

"That will do," we said to Moxton, and almost at once, like a denizen of the deep, the Star Climber clove the surface of the water. 
We looked out, and indeed our journey was ended-we were floating on a calm sea, with a great sun casting its long sloping rays upon us, a blue sky above us, and away a mile on the right was seen the cloud of steam our entrance into the water had raised. Moxton stepped to our outer cabin, closed the door-we waited while we heard the withdrawal of the air tight plugs, then his voice sang out-"All right," and Weir's hand, which had been resting on the levers, gave the motion. Our ceilings and roof, which had seemed so solid for the last four months, began to lift and throw themselves back, till we stood out on the deck-fell in the free air-a slight breeze sweeping over us, and a slight swell rising and falling along the sides of our vessel.

\section{CHAPTER XI.}

After all our troubles we were landed safe. We were floating on an ocean of another world-'twas not quite the same as that we left-it seemed both clearer and softer, for a long way down we could see, and for a long time saw nothing but water, then shoals of fish came round-not fish such as we have on earth-but fish of pronounced forms-fish with fins like handsfish with elongated fins-on which we did not doubt they could walk when in a shallower water. But then stranger than all we saw them form bands, and glide past us in ranks with a leader waving his long fin-like arm, directing or beckoning them.

Now, too, we began to feel the changing atmosphere. Night was coming on-but what was night to us. We knew that all around the northern pole of the planet was spread the long six months' day, and again rising from the ocean, we swept onwards.

Two hours landed us in another climate, we got away from the forests and water out on to a vast high dreary plain, with the sun about ten degrees above the horizon.

Away to the north stretched the limitless desert, and all around us a huge waste of sand.

Here again we rested and took counsel-for nothing like human life had we seen, and not a bird in the air. We had seen troops of beasts cropping the herbage on the open ground, but had gone on wondering and hoping.

And there in this solitary place we determined to spend the night-at least our night. We put out our gangways, and descended to the ground; we walked around our vessel and looked at her closely. She was not that 
blue and gold and silver creation which left the other world; the cankerous mist through which we passed had spoiled her beauty, yet otherwise she was as sound as when we started in her.

It was an intense relief to stretch our limbs by walking on the solid earth. During our voyage, where a hasty step would send you flying up against the roof, and even the heaviest things were without appreciable weight; our muscles had, despite our best endeavours, become relaxed and weakened, and we found a very slight amount of exercise sufficient for us.

As we returned to our boat, Weir was, as usual, in the most frolicsome of humours, and I almost in the opposite mood.

I mentally compared myself to the seer in the Revelations-"Behold! one woe is past, and another cometh quickly." It was the thought of the coming days of solitude, when Weir and Moxton should have gone back to the world, yet not thought in its purity, but the thought debased and made painful by an understratum of want of faith in the new generation. Weir, perhaps, rightly interpreted it, when he exclaimed-"Yes, truly you will be a second Adam, but where, alas, is thy Eve? Never mind, Hope, perhaps an old cherubim may turn up to keep you company. You could lodge him in the tent, you know."

But I could not joke with him; strange and new ideas were thronging my mind. Moxton, seeing this, brought out the real aqua vitae, and we drank in liquor that might have been distilled from the veins of the ancient Gods-"To the new world, and to our farther success."

"Twas a wondrous medicine-all that alcohol seems to the savage, when he feels it tingling with pleasure through all his veins, and throwing a glamour of light over his very soul.

Like alcohol, too, the excitement it caused was very great; even a strong brain would go wild with delight, and under a regime of excess, the overpowered subject seemed led as by Houries in a flowery way; seemed to rest on beds of asphodel and live in joy; the opium smokers' heaven was always his, meat and drink were no longer needed, the swiftly attenuating body seemed a cage too fragile to hold the soul which would step laughingly over the portal of death.

While, on the other hand, if used with due discretion under its glorious influences, these soft, the frail bodies of ours-if uninjured by accident, if not crushed by brute force-might outlive the very world we stood on, and who could say, perchance, even the system that this world is moving with- 
yea, why should we not go out with the speed of a comet on the thousand years' journey to another sun-another system.

We-Moxton Weir and I-all believed in this elixir. Our lives were, if not supremely blest, very happy, and had we not even now solved the great problem and opened out a dwelling-place for the people of the future, we did not doubt that next generations would surpass us as much as-"Yes," I said aloud, "as much as you do me." Nor could I repress a return of that distrustful bitter feeling which seemed to well up from some unknown and longer buried spot in my heart-I had scarcely felt it since Edith Weir had given me her love.

I wished them at that moment to come over and clasp me by the hand in old world fashion, and to say that we stood or fell together, that they would be always with me.

But Moxton smiled almost in pity. "Those feelings of yours, Hope, are the strangest relics you preserve of the past. You carry fear like a devil in your heart, and every now and then he rises up and frightens you. The reign of violence is nearly done, and should the world ever weary of you and need the air you breathe for better lips, it would but be like a cry of conscience to you, never articulated or breathed through any tangible mouth or spirit, it would be no cause for fear. I am sure you could now for the good of humanity resign with a calm mind, your body to the dust." I did not answer, for they both knew my thoughts, and I think both felt a longing for those softer spirits, those kinder natures, those eyes which even now, now and again, knew tears. I know that in my heart Edith was again enshrined, chasing worlds and systems and planets far away, and filling it with herself, till my breath came quicker, and mine eyes grew bright under her influence. She was there so truly-"so near and yet so far." We looked out and saw the great sun moving round, and felt the air thin and keen, yet tempered by his beams. We took a last glance around, making all things safe; and then, for the first time since leaving our present earth, we all slept, resolving to visit together all the wonders of the new world, and to see together all that we should find.

\section{CHAPTER XII.}

The poles of the planet Venus are at such an angle that about half the planet enjoys alternately a day of three months - a long dim day of twilight, and then night; as a natural consequence, the regions approaching this 
country are strangely affected. When we woke in the morning we saw the first proof of this in the low sun, still hanging at the same altitude, the livelong night he had been thus creeping around, so that here there was no day or night, morning or evening, and the waste of desert around us seemed as if made for these monotonous periods.

We spread out the wings of our vessel and went on our way-but found the land still rising as we went north-and though the cold did not increase with the increasing altitude, as it would on the earth, the air grew thinner, and the barometer sank lower and lower, till it touched the fourteenth inch, and breathing became very laborious work.

We had determined to go right over the pole of the planet, but, as we did not like to shut ourselves up again, we were soon obliged by the rarefied air to turn to the lower and warmer regions, going away swiftly till grass and wood and water again began to reign, then sailing slowly, and not too high, that we might observe if anything like humanity should appear. We saw troops of beasts, four-legged and two-legged ape-like creatures, kangaroo, or more properly three-legged animals; but none of them seemed struck with wonder as we glided slowly above them. They all fed and played and fought, as though there were nothing new under their Heaven, and if we swept down near them went away with screams and cries to their shelters. Their forms were very strange, ever recalling something we knew, yet always differing from it; yet what we most noticed-what seemed to be an unvarying characteristic-was that, whether large or small, they all moved in troops and bands, all fed and fought together, and all seemed well provided for either attack or defence; but nothing human appeared, nought of a nature similar to our own.

I can hardly tell how much we wished-how our hearts would have gone out towards any living creature which should have risen above the level of the animal world, or how out thoughts wondered over the intellectual union which might arise, should two such experiences join their pleasures, their results; yet here there was enough to recall the wildest wandering thoughts, as we went hither and thither to and from every new object, everything that promised a revelation, over lakes and mountains, rivers and forests, till we felt ourselves in the tropical regions, with the high sun blazing overhead, and the great bush herbage, and vast trees all about us.

Yet none of this would please Moxton, he would press on to the winter half of the planet, to the land of shadow, and we expected of ice and snow, for warm as the planet was, we thought that three months' exclusion from 
the sun's heat, would bring the temperature very low. Yet we could not help lingering, turning to each new beauty of flower and fruit, leaf, or herbage, skimming near the edge of the forest, or the waters of the rivers, hoping to see some new elephant or huge mastodon, for the appetite for the wonderful, not sufficiently substantial I suppose, for Solomon's classification is, however, one of the hardest things to satisfy, so far from ever crying enough, it grows with its food.

So we were borne steadily onward through the fresh air of the new world-were always eager to behold something fresh-unsatisfied with the wonders of Heaven. We seemed to forget the leagues that we had travelled, unmindful of our great fate, to run like older babes in the wood from flower to flower as fancy guided us.

Yet stopping often as we did, our immense speed led us fast from clime to clime, and before the natural day would decline the sun began to grow low on the northern horizon; the tropical forests to be replaced by grassy plains and rolling, scantily timbered hills. Sometimes, too, we came on arid sand-huge dry deserts without even the proverbial vulture to enliven them; then succeeded strange twilight, with the sun low down, and its beams striking along the world-. The air seemed to grow vague and yellow, a thickness and fogginess pervaded everything. How changed seemed the vegetation-rotting leaves and bare boughs; huge stalked grass, half-decayed-and here, too, we saw more birds, great downy owls, and bats to which the devil of the middle ages was a mild creature. It also seemed the land of frogs and toads-huge speckled tawny creatures, not good to look at; and the vegetation altered fast now, the reign of the fungus seemed to have begun. The ground, the trees, the water were covered with minute forms, and in the opener spaces huge growths stranger than the cactus or fungus of the world, immense groups of all shapes, so strange were they, that even Moxton agreed to come to a stand for a while.

We left our vessel and walked among these wonders-taking, however, our weapons with us-we seemed like the little men of Gustave Doré, walking in some strange ante-diluvian world. Now they rose around us like the groups of miniature towers with their snow-white tops and their fleshcoloured interiors; others would strike away in convolutions over yards of ground in disgusting mimicry of a dissected animal; others built up of narrow ridges and spines, and every interesting shape, and every shade and colour-some beautiful, some hideous. One large flower-like thing, like a thick-lipped convolvulus, had attracted us, and Moxton thrust his 
stick into it-its anthers closed immediately on it, then its thick leaves folded down with a wonderful grip, but if Moxton was the first to be surprised, the would-be glutton was the next. With scarcely any visible motion beyond the setting of his muscles, he set the magnetic power of which he had a wonderful command, thrilling into the flabby monster. The effect was instantaneous, it curled for a moment as under galvanic action, then its whole system collapsed and seemed to fall into itself in flaccid weakness, while its juices exhaled and dripped from its whole surface.

Perhaps had we seen these things under the broad sunlight, they would have made like impression, but the strange light, the long shadows, and the great patches of colour, the result of minute organism, covering both earth and water, made them strange and wonderful to look on, like a peep show of Dame Nature; but it was not good to stay in, and our curiosity being satisfied, there was nothing to keep us.

We went to the Star Climber, which seemed more like a home than it had been for months past, and we felt quite a pleasure as we trod once again the familiar deck. We passed on over miles and miles of this twilight country, the sun going lower and lower till every little hollow was in perpetual shade, and there seemed no end to the shadow of a tree. We had still our decks open, and could perceive the chilling temperature. This did not seem the region of storms, but an unaltering, unrelieved, steady rawness gradually verging into a pronounced state of cold. It was many hundred miles before we came to the real ice and snow, where the water was all locked up, and all the ground covered with the downy mantle, but here again we saw occasionally troops of beasts dashing away in the dim light, and a solitary large-eyed bird rose and flitted into the darkness that spread around us. The stars were very faint, the air did not seem yet to be clear of the mist and lingering sunshine, and there above us-a dim star amongst thousands-lay the earth, our native home; and as we looked at it the thought that we should soon stand there again seemed to partake of impossibility and madness.

Weir said, "I wish you would not think so dismally, Hope; those ideas of yours would unstring the nerves of a lion. There is nothing renders a man so helpless as that sense of fatality and impossibility."

Moxton said with a laugh, "I should think it would be less trouble for you to rule against the entrance of Hope's ideas than for him to perfectly control them." 
This brought a smile to our faces, though from different feelings. Weir was always kind-natured. My smile was, I suppose, so grim that Moxton, looking at me, said, "Well?"

I answered, "I do not care what either of you think when I feel like this."

"No," replied Moxton, "the human brain was so dulled and attuned to sorrow through many centuries, that the sentiment of it is bound to be pleasant, wakening as it does all the half forgotten motions. 'Tis the same in kind as that the old athlete feels after years of disuse he stretches his muscles again."

But it was growing cold. We agreed to again shut down the outer covering of the Star Climber, as Moxton wished to run through this region of darkness, and as we sped on our way it grew brighter, the air seemed clearer, the ground sparkled with snow and frost; the rivers and seas were coated with ice, a thorough winter reigned all around us. 